\title{
EARLY APPEARANCE OF LARGER FORAMINIFERA SUPPOSEDLY CHARACTERISTIC FOR LATE EOCENE IN THE IGUALADA BASIN, NE SPAIN
}

\author{
Josep ROMERO', Lukas HOTTINGER ${ }^{2}$ and \\ Esmeralda CAUS ${ }^{\prime}$
}

' Dep. de Geologia. Universitat Autònoma de Barcelona. Bellaterra (08193).

${ }^{2}$ Museum Natural History. Augustinergasse 2, Basel. CH-4000.

Romero, J., Hottinger, L. and Caus, E. 1999. Early appearance of larger Foraminifera supposedly characteristic for Late Eocene in the Igualada basin, NE Spain. [Aparición previa, en la cuenca de Igualada (NE España), de macroforaminíferos supuestamente característicos del Eoceno Superior]. Revista Española de Paleontología, 14 (1), 79-92. ISSN 0213-6937.

\begin{abstract}
The redescovery and exact location of Biplanispira and abundant, free Pellatispira on the slopes of Puig Aguilera in the Igualada basin triggers the discussion about the age of the first appearance of so many other genera considered so far as restricted to the Priabonian.

In the Igualada basin, Biplanispira, Pellatispira, Heterostegina reticulata and Silvestriella are found together with other, larger foraminifera considered older than Priabonian, i.e. with Nummulites ptukhiani, Assilina schwageri and $A$. roselli. These latter species belong to lineages known to evolve continuously from Lutetian to Priabonian. The three representatives of these phyla concurrently indicate a Bartonian age of the sediments yielding Pellatispira and its associates.
\end{abstract}

Keywords: Larger Foraminifera, Biostratigraphy, Middle-Upper Eocene, Spain.

\section{RESUMEN}

El redescubrimiento y la exacta localización de Biplanispira y la presencia de abundantes Pellatispira en las laderas de Puig Aguilera, en la cuenca de Igualada, reabre la discusión sobre la edad de la primera aparición de muchos otros géneros, considerados hasta ahora típicamente priabonienses.

En la cuenca de Igualada, Biplanispira, Pellatispira, Heterostegina reticulata y Silvestriella aparecen asociados a otros macroforaminíferos considerados anteriores al Priaboniense, como por ejemplo Nummulites ptukhiani, Assilina schwageri y A. roselli. Estas especies pertenecen a linajes conocidos, los cuales evolucionaron ininterrumpidamente. Los tres representantes de estos linajes indican una edad Bartoniense para los sedimentos situados por debajo de los que contienen Pellatispira y sus asociados.

Palabras clave: Macroforaminíferos, Bioestratigrafía, Eoceno Medio-Superior, España.

\section{INTRODUCTION}

Difficulties in correlating late Middle Eocene and Upper Eocene deposits are the reason why, between the Lutetian and the Priabonian stages, there are a multitude of stage names partially or totally overlapping in time (Bartonian in the Paris Basin, Biarritzian in the Pyrenean realm, Napocian in Romania, etc.) The International Subcommission for Paleogene Stratigraphy has pinpointed the Middle-Upper Eocene boundary therefore as a prioritarian target for revision and redefinition.
From the paleontological point of view, between the end of the late Middle Eocene and the beginning of the Upper Eocene, there is a major faunal change characterised by :

1. the disappearance of large sized nummulites species such as $N$. perforatus, $N$. brogniarti, N. puschi, N. biedai, Assilina exponens, etc. (see Schaub, 1981).

2. the appearance of nummulitic genera such as Heterostegina and Spiroclypeus as well as Silvestriella, Pellatispira, Biplanispira, etc.

3. the persistence of nummultic phylogenetic lineages 


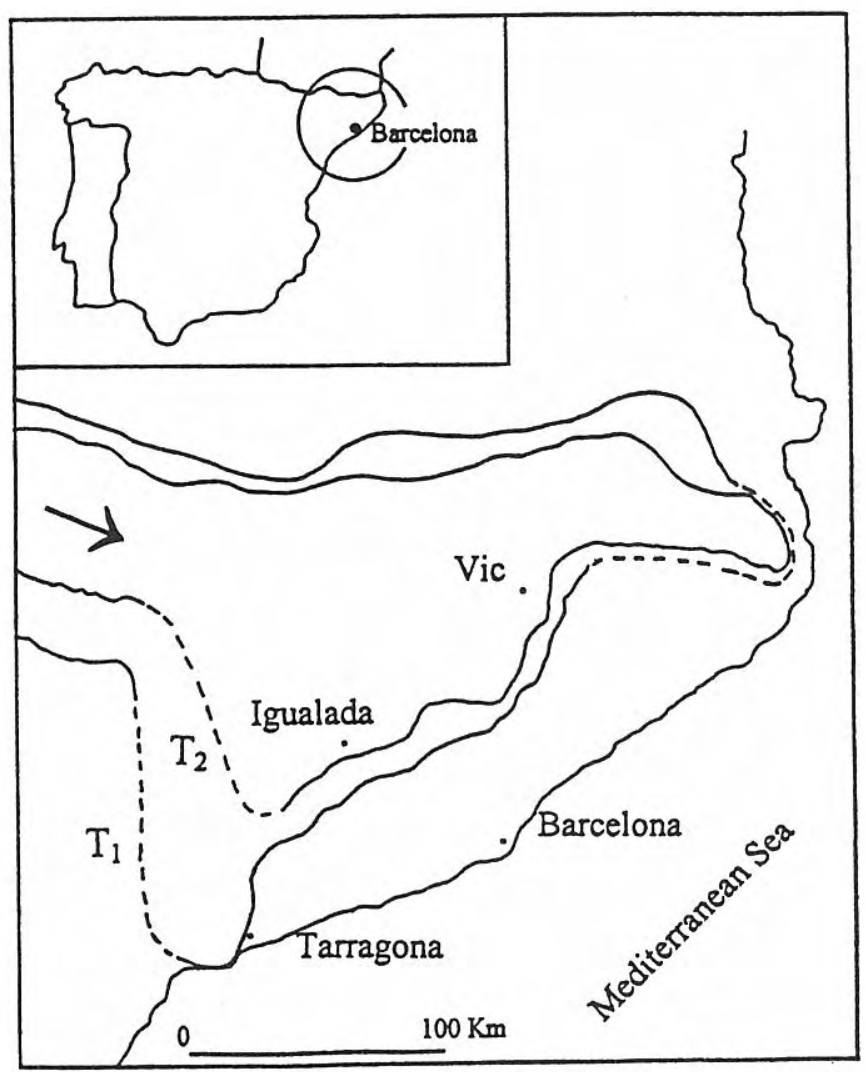

Figure 1. Sketch map of the location of the two marine cycles that affect the studied area $\left(\mathrm{T}_{1}\right.$ : Ilerdian and $\mathrm{T}_{2}$ : Bartonian). The arrow indicates the sense of the transgressions. such as N. ptukhiani (see Schaub, 1981) to N. fabianii, "Operculina" schwageri to "Operculina" alpina,

"Operculina" bericensis to "Operculina" gomezi, etc.

4. the persistence of smaller rotaliid phyla such as Neorotalia viennoti and Rotalia (s.str.) trochidiformis.

5. the persistence of other benthic genera with complex structures such as Fabiania, Eorupertia, Halkyardia, Chapmanina, etc. of which some will survive also the Eocene-Oligocene boundary.

6. in the upper part of the photic zone corresponding to the Orbitolites-Alveolina communities, current knowledge on the faunal turnover is so scarce that no survival patterns can be recognised at present.

7. in the lower part of the photic zone corresponding to Discocyclina-dominated communities, the effect of the boundary events seems to be much reduced.

So far, this faunal turnover has been used to distinguish Late Middle Eocene from Upper Eocene in shallow water, interpreting the events as synchronous. In terms of evolutionary ecology, the synchroneity of this faunal turnover makes no sense and is to be considered as an artefact due to insufficient resolution power of biostratigraphy during this period of time. The project "Neritic Events at the Middle-Upper Eocene boundary" of the International Geological Correlation Program (nr. 393) will provide a working instrument to co-ordinate the biostratigraphic and paleontological aspects of research on this subject and to integrate its results with the ongoing research on sequence- and magneto-stratigraphy.

The work presented here analyses what happens in the shelf facies during this interval of time in the Igualada Basin.

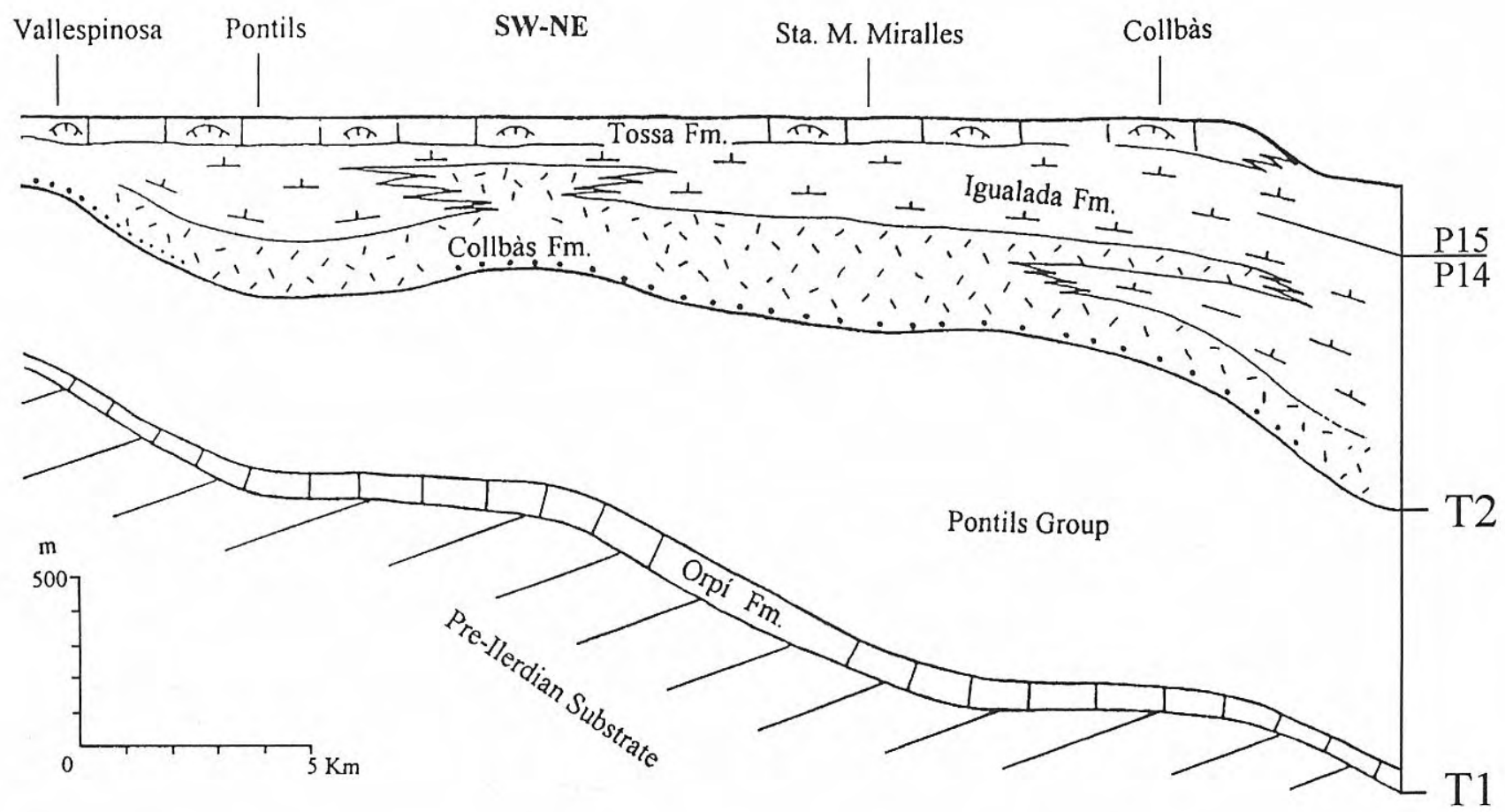

Figure 2. Stratigraphy of the area and the location of P14 / P15 boundary. T1 and T2 as in Fig. 1. Modified from Anadón and Marzo (1986). 


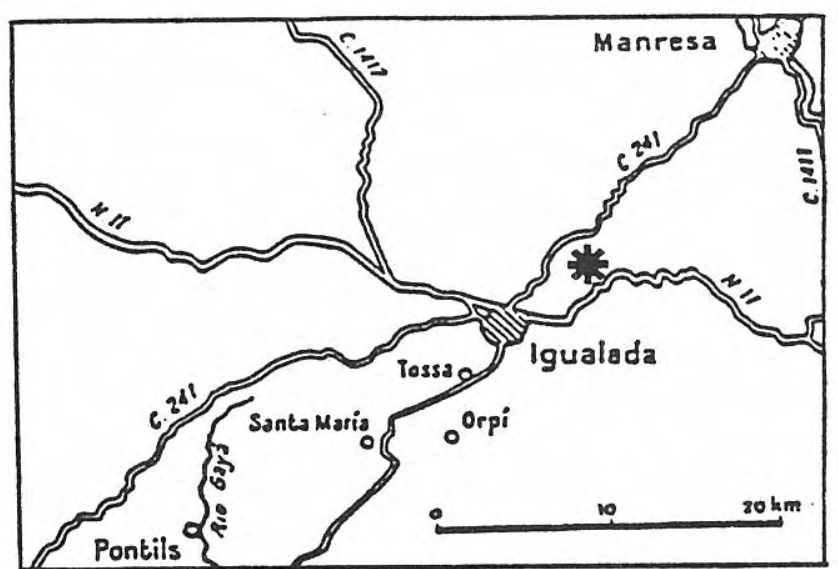

Figure 3. Sketch map of the location of Puig Aguilera.

\section{THE IGUALADA BASIN}

The so-called Igualada Basin represents the southeastern end of the Sudpyrenean Early Tertiary Basin. The Paleogene marine deposits are linked to two marine cycles (Figs. 1 and 2): the first one, Ilerdian in age, produced the Alveolina limestone from the Orpí Formation (Ferrer, 1971a). Its outcrops extend until Cape Salou in the Mediterranean sea (Colombo and Caus, 1984). The second cycle began with the deposition of yellow to blue-grey argillaceous siltstone with intercalations of limestones rich in larger foraminifera, mainly Nummulites, and corals of the Collbas Formation
(Ferrer, 1971a). It is stratigraphically followed by the Igualada Formation (Ferrer, 1971a) composed of blue grey marls and the Tossa Formation (Ferrer, 1971a) consisting of coral limestones. These three formations constitute the Santa Maria Group (Ferrer, 1971a). The marine formations are separated by the Cuisian to Lutetian-Lower Bartonian continental deposits of the Pontils Group (Anadon, 1978).

The boundary between Truncorotaloides rohri (P14) and Globigerinatheka semiinvoluta (P15) biozones in the Igualada basin was recognised within the blue marls of the Igualada Formation by Ferrer (1971a) and Anadon and Marzo (1986) (see Fig. 2). The shallow shelf deposits of the Tossa Formation have been attributed to the Lower Priabonian because they are deposited on top of the blue marls and by the presence of Heterostegina, Pellatispira, Biplanispira, etc. (Ferrer, 1971a, b). According to SerraKiel et al. (1998), the limit Middle-Upper Eocene, defined by the replacement of $N$. ptukhiani by $N$. fabianii, is placed within P15. Accordingly, the Upper Eocene would not be represented in the area by marine deposits as reflected by the absence of $N$. fabianii in the whole basin.

The present study is centered in the Puig Aguilera area which is situated $2.5 \mathrm{~km}$ to the east of the Odena village (Fig. 3). We have chosen this area because Ferrer (1971b) had pointed out the presence of "Priabonian" Pellatispira and Biplanispira?. Sofar, the latter genus was know only from the Far East, in particular from Indonesia. None of the various litho- and/or biostratigraphic subsequent studies made in the Pyrenees

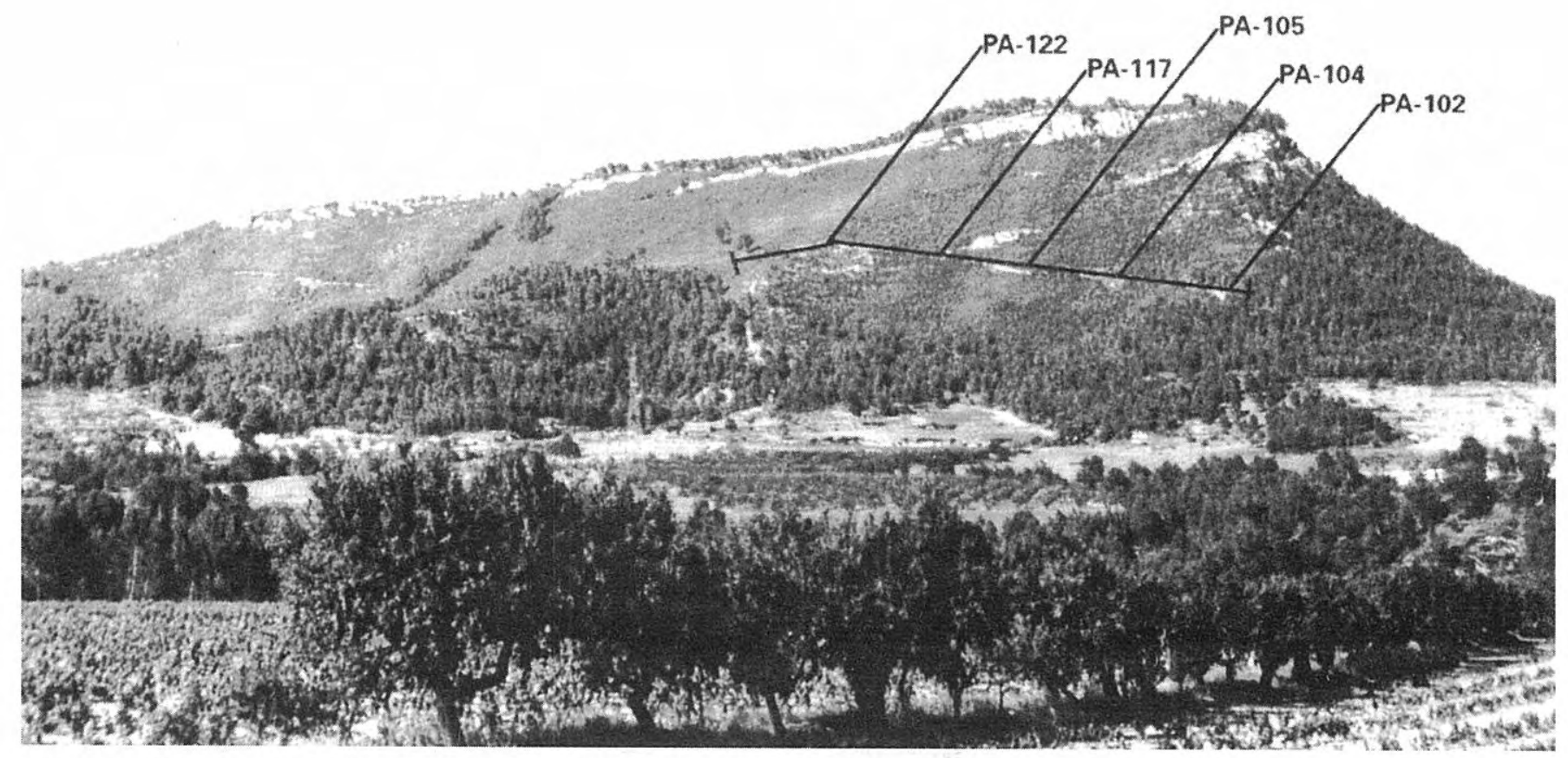

Figure 4. Situation of the Puig Aguilera stratigraphic section and of some selected samples. 


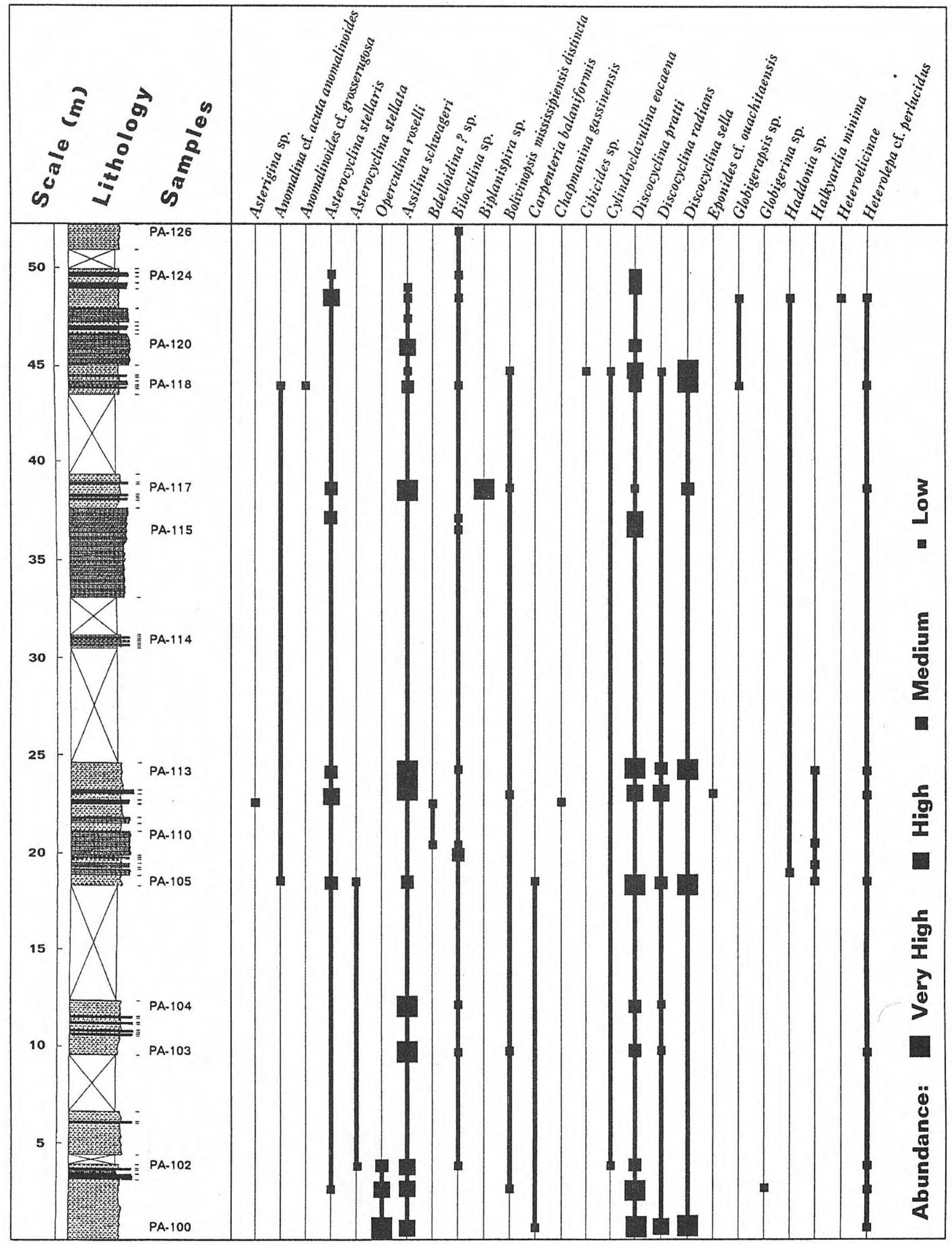

Figure 5. Stratigraphic section of Puig Aguilera with distribution of selected smaller and larger Foraminifera and other fossils. 


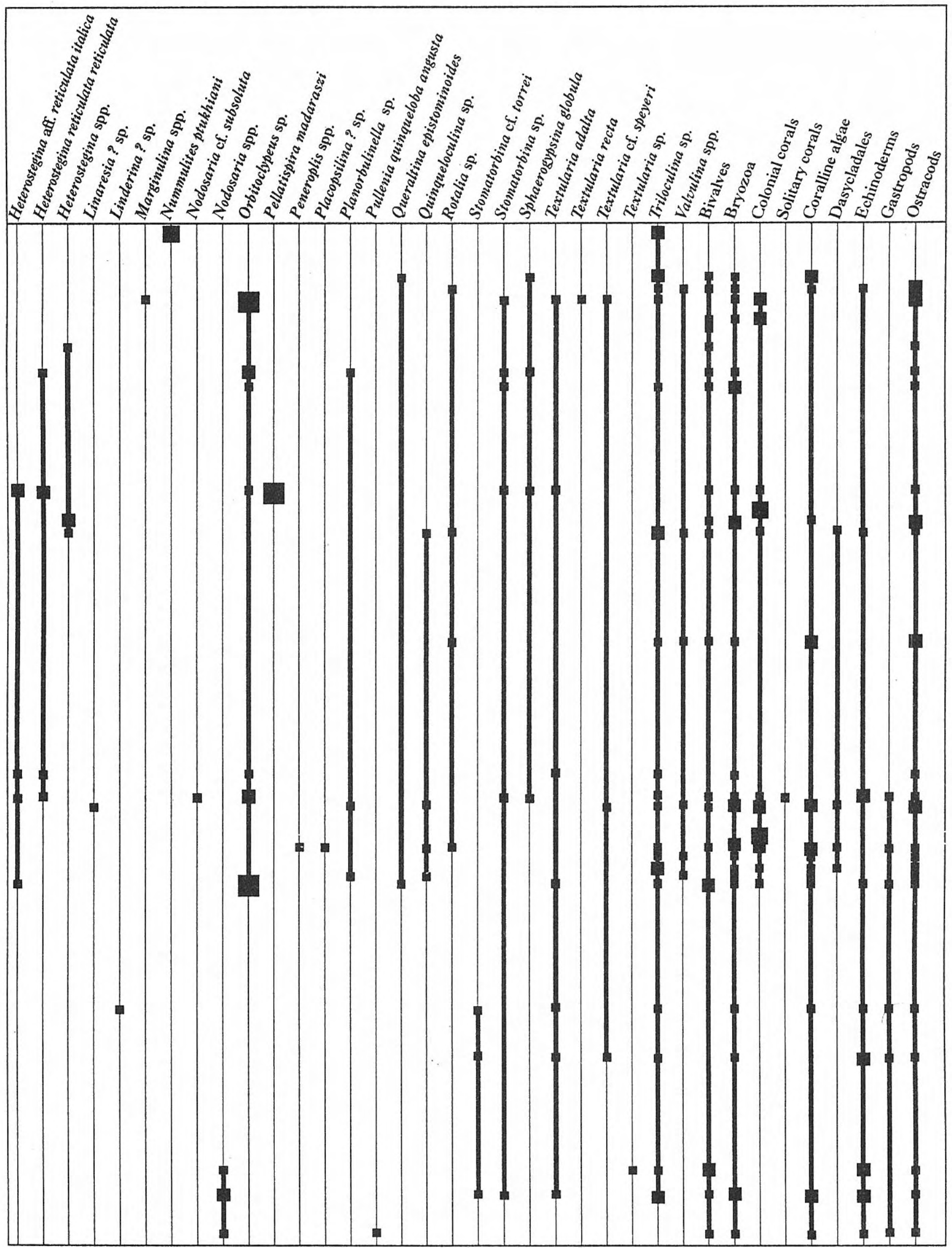


mention these genera again, until Romero (1996) rediscovered them on the Puig Aguilera. Nevertheless, the presence of Heterostegina and Pellatispira was pointed out in the Oliana anticline, in carbonate sediments given as equivalents to theTossa Formation (Caus, 1973).

A detailed section has been made on the western slope of Puig Aguilera extending through the transitional beds from the Igualada to the Tossa Formation where 29 samples have been collected from a total thickness of 53 $\mathrm{m}$. The lay-out of the section (Fig. 4) was fixed in view to avoid the bioconstructed carbonate bodies usually cemented and therefore difficult to wash and in the same time too shallow to yield useful index fossils. The paleontological study is focused on the evolution of the operculiniform genera Assilina (ex-Operculina) and Heterostegina and on the apparition of Pellatispira and Biplanispira. A list of additional selected microfaunal content is also given (Fig. 5). The studied material is deposited in the Departament de Geologia de la Universitat Autònoma de Barcelona.

\section{SYSTEMATIC DESCRIPTIONS}

\section{PRELIMINARY REMARKS ON GENERIC NAMES USED}

In larger foraminifera, at least from the Mesozoic and the Tertiary, by general consensus, the genera are distinguished by qualitative characters, i.e. differences in structural patterns. The species are distinguished by quantitative differences in the shell morphology expressed by sizes, proportions or shapes exhibiting a specific variability. The generic names identified and used here follow strictly this concept. The use of the name Assilina in particular for species classified traditionally under the name Operculina needs some additional comments: Hottinger (1977) could not find a difference in architecture between shells formerly called Assilina and Operculina. He united therefore the two genera under the name Operculina d'Orbigny, 1826, name prior to Assilina d'Orbigny, 1839. The type species of the genus Operculina was subsequently designated by Cushman in 1914 as Lenticulites complanatus Defrance, 1822. In his paper of 1914 however, Cushman illustrated "O. complanata" by recent specimens representing the species Assilina ammonoides Gronovius, 1781, not the Oligocene species O. complanata (Defrance, 1822). Hottinger (1977) based his concept of the genus Operculina rather on the specimens figured by Cushman (1914) than on the name given to them in the same plublication as type species of the genus Operculina. Loeblich and Tappan (1987) correctly point out that the concept of the species is linked to the species name, and not to the specimens a subsequent designator may have used to illustrate the species erected by someone else. Thus, Operculina must be conceived as corresponding in structure to the Oligocene $O$. complanata (Defrance, 1822) (not Cushman) which has a more or less folded septal flap, whereas Assilina (type species Assilina depressa d'Orbigny, $1850=$ Nummulites spira Roissy, 1805) has an unfolded septal flap. This latter character is present in all species attributed traditionally to Assilina (phyletic groups of $A$. spira and $A$. exponens, sensu Schaub, 1981) as well as to the phyletic groups traditionally called "Operculina", such as A. ammonea, A. canalifera, A. alpina and A. ammonoides sensu Hottinger, 1977. Operculina gomezi group shows a tendancy to fold the septal flap and remains therefore until further notice, in the genus Operculina.

Neither the path of the spiral nor the rate of involution can be considered as qualitative, structural characters for the distinction of genera. Therefore, the genus Grzybowskia Bieda, 1950, introduced to designate the late Eocene, involute heterostegines is not used here, following Hottinger (1977), Herb (1978) and Loeblich and Tappan (1987).

\section{Assilina d'Orbigny, 1839}

\section{Assilina schwageri (Silvestri, 1928) Figs. 6 and 7}

1928 Operculina schwageri Silvestri, 112.

1964 Operculina cf. alpina Douvillé; Hottinger, 1020, pl. 3, figs. $1-3$; pl. 5 , figs. 4,5 .

1971 Operculina alpina Douvillé; Ferrer, 34, text-fig. 18.

1975 Operculina aff. alpina Douvillé; Caus, 176, fig. 2.

1977 Operculina schwageri Silvestri; Hottinger, 82-84, pl. 38 , figs. 1-3; text-figs. 4A, 31A, 32 .

Among the specimens found in the Puig Aguilera section belonging to this species, two different megalospheric morphotypes can be distinguished. The first one has an adult shell diameter which varies from 3.05 to $5.65 \mathrm{~mm}$; its megalospheric proloculus diameter reaches from 0.085 to $0.162 \mathrm{~mm}$. The second morphotype has a diameter varying from 2.75 to 4.60 and its megalosphere from 0.060 to 0.150 . Its chambers are wider than in the first morphotype and present a distinctive ornamentation by fields of interseptal piles. The coexistence of the two distinctive morphotypes in the same samples could indicate either two different habitats (for instance: different exposition to the water energy, and/or light) or two different A-forms corresponding to a schizontic and a gamontic generation. Only one microspheric morphotype is represented by some rare specimens (Fig. 6B).

In recent "Operculina" ammonoides, a depthdependant, bimodal frequency distribution was observed for the megalosphere and second whorl diameters (Fermont, 1977; see also Reiss and Hottinger, 1984, p. 230).

From bottom to top of the section, the megalosphere diameter increases in both megalospheric morphotypes (Fig. 8). The earliest diameters overlap with megalosphere sizes belonging to the Lutetian A. parva (Douvillé) (see Hottinger, 1977 , p. 81), the latest diameters of 140$160 \mu \mathrm{m}$ do not reach the sizes typical for Priabonian $A$. alpina (Douvillé). Thus, the specimens measured here 


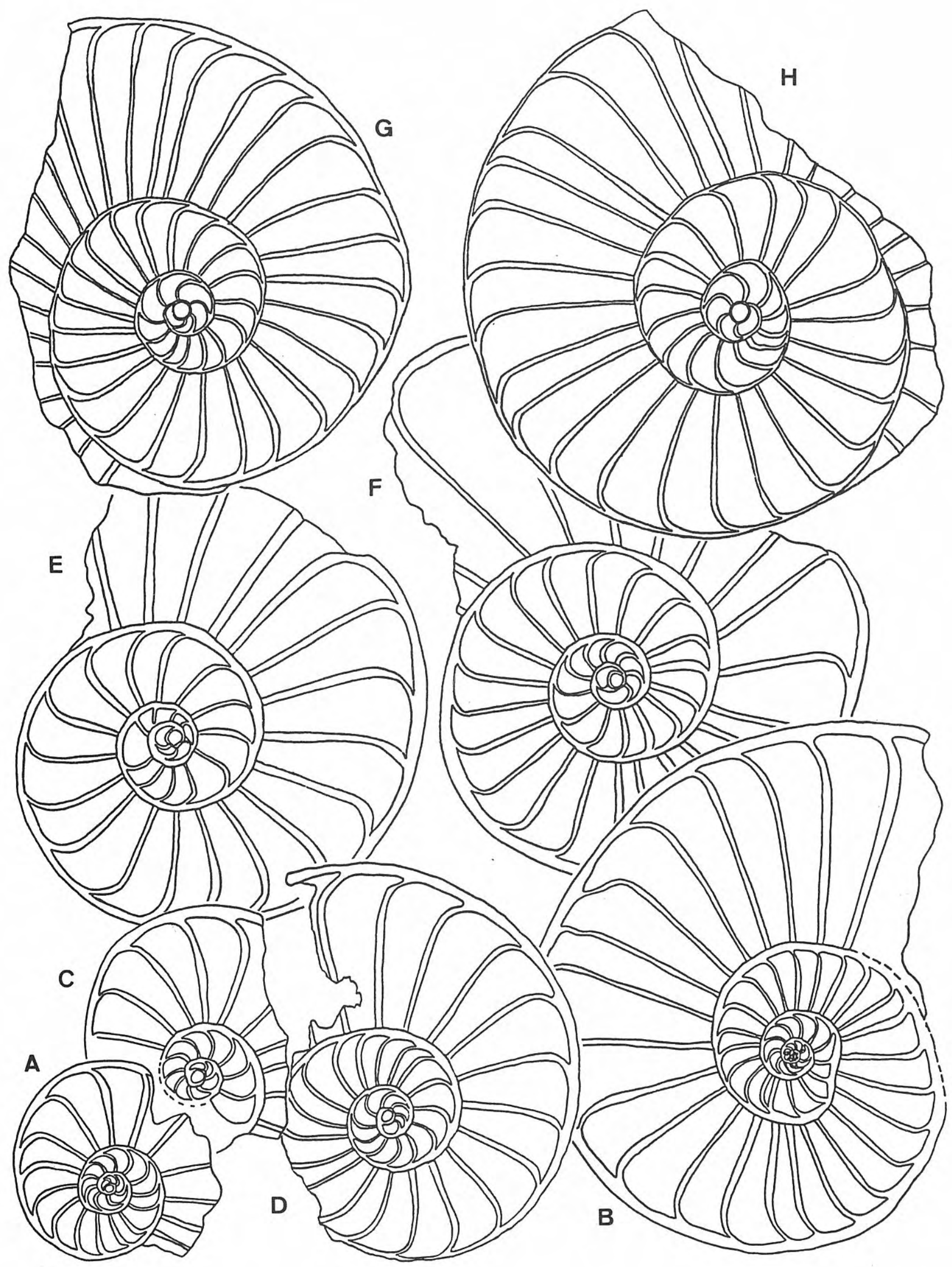

Figure 6. Assilina schwageri Silvestri. Equatorial sections. Morphotype 1. x 20. Camara lucida drawings. A: PA-101, B: PA101 (microspheric form), C: PA-102, D: PA-103, E: PA-104, F: PA-105, G: PA-112 and H: PA-113. 


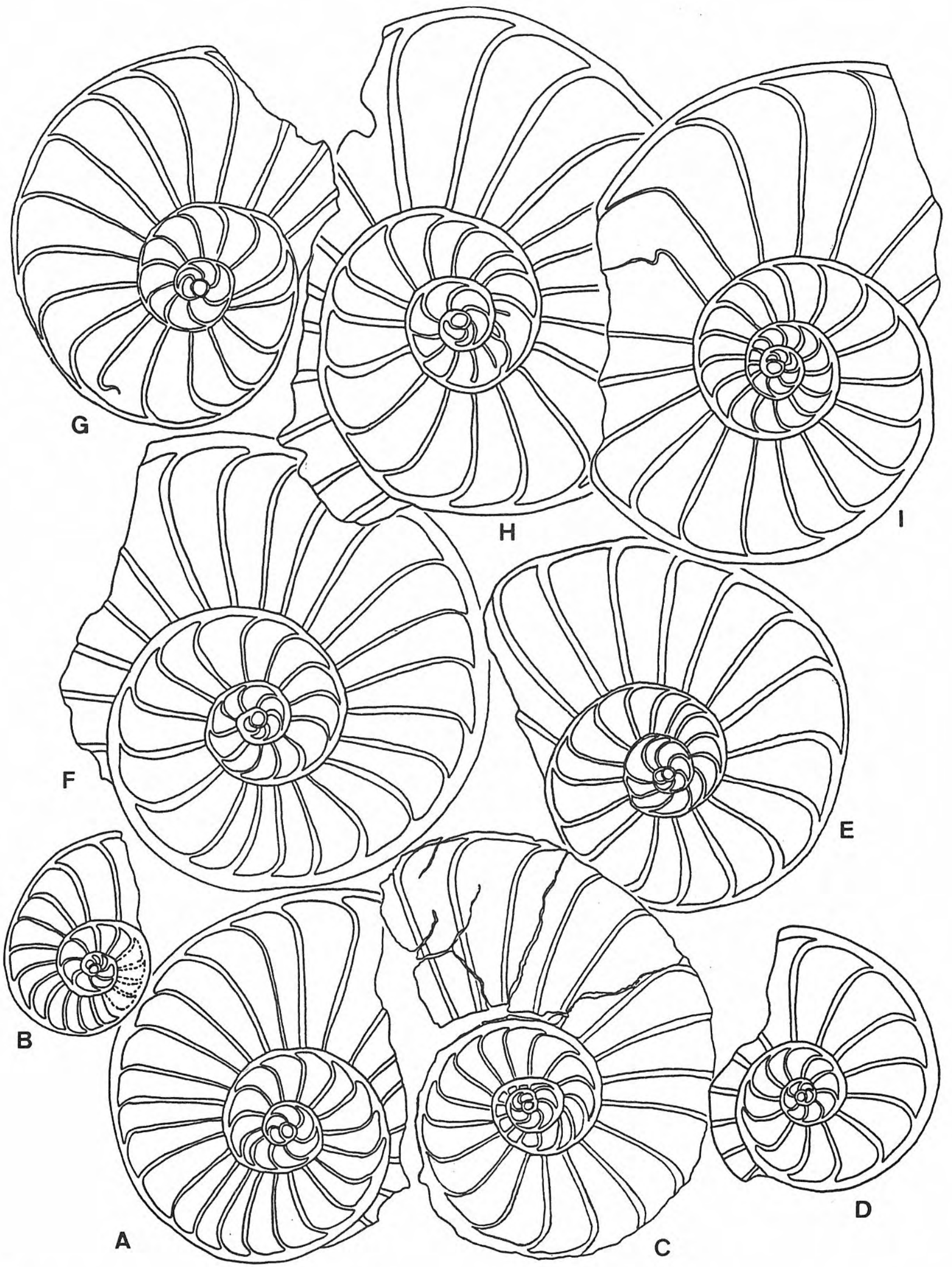

Figure 7. Assilina schwageri Silvestri. Equatorial sections. Morphotype 2. x 20. Camara lucida drawings. A: PA-100, B: PA101, C: PA-102, D: PA-103, E: PA-104, F: PA-105, G: PA-112, H and I: PA-113. 


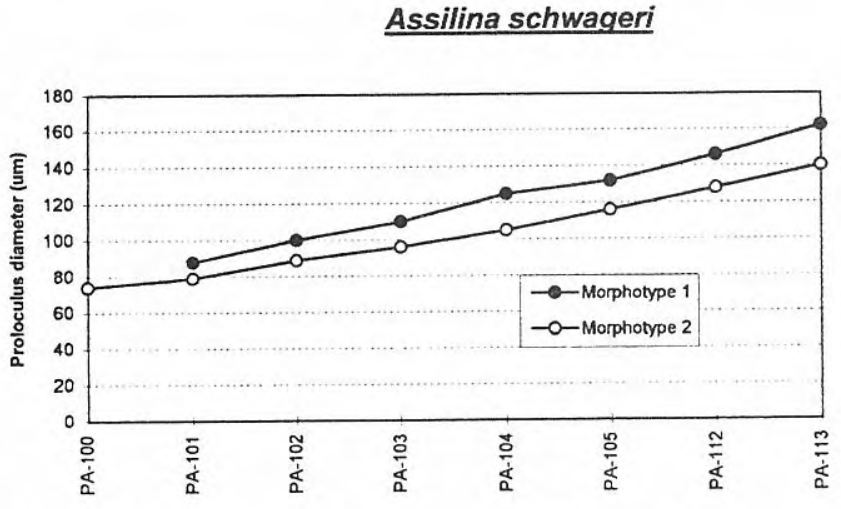

Figure 8. Diagram for proloculus diameter of morphotype 1 and 2.

belong to A. schwageri Silvestri as described first from the aegyptian Bartonian.

Operculina d'Orbigny, 1826

\section{Operculina roselli Hottinger, 1977 Fig. 9}

1964 Operculina canalifera gomezi Colom and Bauzá; Hottinger, 1022, pl. 6, fig. 3.

1971 Operculina canalifera gomezi Colom and Bauzá; Ferrer, 35, fig. 19.

1977 Operculina roselli Hottinger, 97, figs. 4B, 37A-C.

The specimens carrying the typical ornamentation on the involute shell part characterising $O$. gomezi group (Hottinger, 1977, fig. 4B) found in the Puig Aguilera section are identified as $A$. roselli due to the small diameter size (from 1.85 to $3.28 \mathrm{~mm}$ ) of the adult test and also the smaller proloculus size (from 0.112 to 0.142 $\mathrm{mm}$ ) as compared to the Priabonian O. gomezi (Colom and Bauzá). Their strongly thickened center is due to a partially involute nepionic stage. The chambers are numerous and narrow. The sutures at the periphery are strongly curved backwards. The lamellar test is finely perforated with a smooth surface. A completely folded septal flap subdividing the chambers like in $O$. gomezi ("Anastegina", see Hottinger, 1977) has never been observed in the studied material.

\section{Heterostegina d'Orbigny, 1826}

\section{Heterostegina reticulata Rütimeyer, 1850 Figs. 10 and 11}

1850 Heterostegina reticulata Rütimeyer, 109, pl. 4, fig. 61. 1950 Grzybowskia multifida Bieda, 151, 167, pl. 3, figs. 1-9, pl. 4, figs. 1,3.

1971 Grzybowskia reticulata (Rütimeyer); Ferrer, 6, pl. I, figs. 5,6 .

1977 ? Heterostegina helvetica Kaufmann; Hottinger, 113, figs. $46, \mathrm{~F}, \mathrm{G}$.

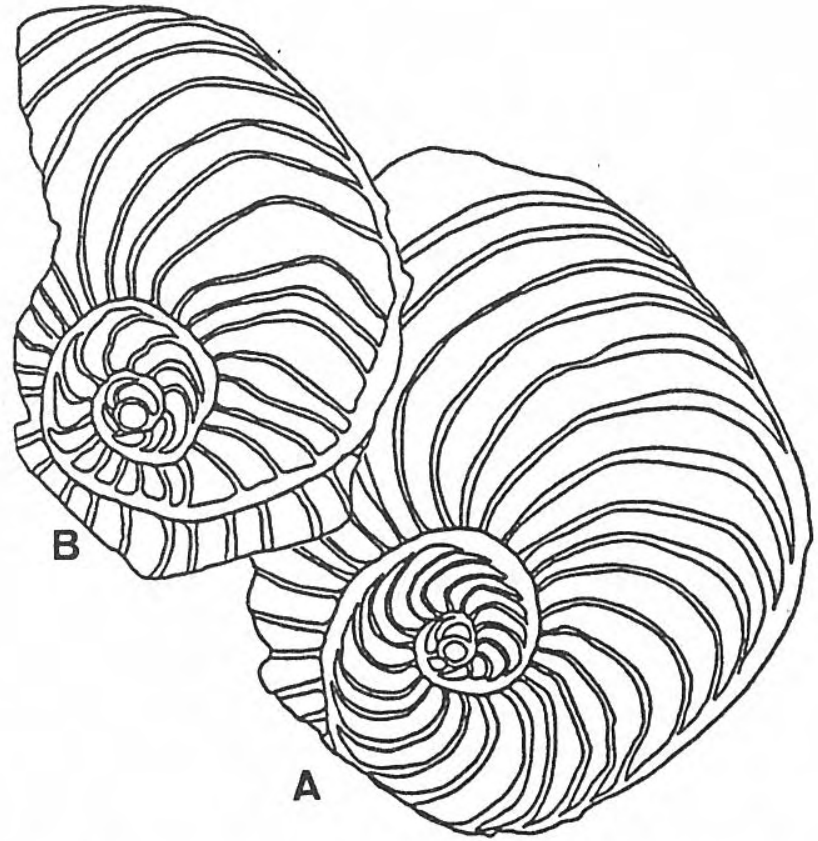

Figure 9. Operculina roselli Hottinger. Equatorial sections. $\mathrm{x} 20$. Camara lucida drawings. A and B: PA-100.

1984 Heterostegina reticulata (Rütimeyer); Caus, 55, pl. 9, fig. 7.

Two morphotypes are identified. The morphotype 1 has a diameter varying from 2.15 to $3.71 \mathrm{~mm}$, with a megalosphere ranging from 0.075 to $0.100 \mathrm{~mm}$ (Fig. 10) followed by $8-10$ operculiniform, undivided chambers. The chamberlets in the following stage have an irregularly rhomboidal outline. The axial sections show that all whorls are involute. According to Herb (1978), morphotype 1 is to be identified as Heterostegina reticulata reticulata.

The adult size of the morphotype 2 (Fig. 11) is much larger (diameter from 3.85 to $4.51 \mathrm{~mm}$ ) than the morphotype 1 . Its megalosphere varies from 0.095 to $0.125 \mathrm{~mm}$ followed by $5-12$ operculinid chambers. Adult chamber divisions are more regular in shape varying from quadrangular to rectangular in outline. The axial sections of the specimens belonging to this morphotype are flatter than in the morphotype 1 and similar to sections of Heterostegina reticulata italica Herb, 1978. However the specimens from the Igualada basin differ from Heterostegina reticulata italica in having a smaller megalosphere: Heterostegina reticulata italica, as revised by Herb (1978), has a megalosphere diameter size varying from 0.140 to $0.200 \mathrm{~mm}$.

The two morphotypes co-occur in the same samples of the studied section and have therefore the same age. As in the A. alpina group, we interpret them as ecological variants or $A_{1}-A_{2}$ generations in a trimorphic reproduction cycle. Taxonomically, we interpret therefore both morphotypes as belonging to a single species, i.e. $H$. reticulata Rütimeyer. 


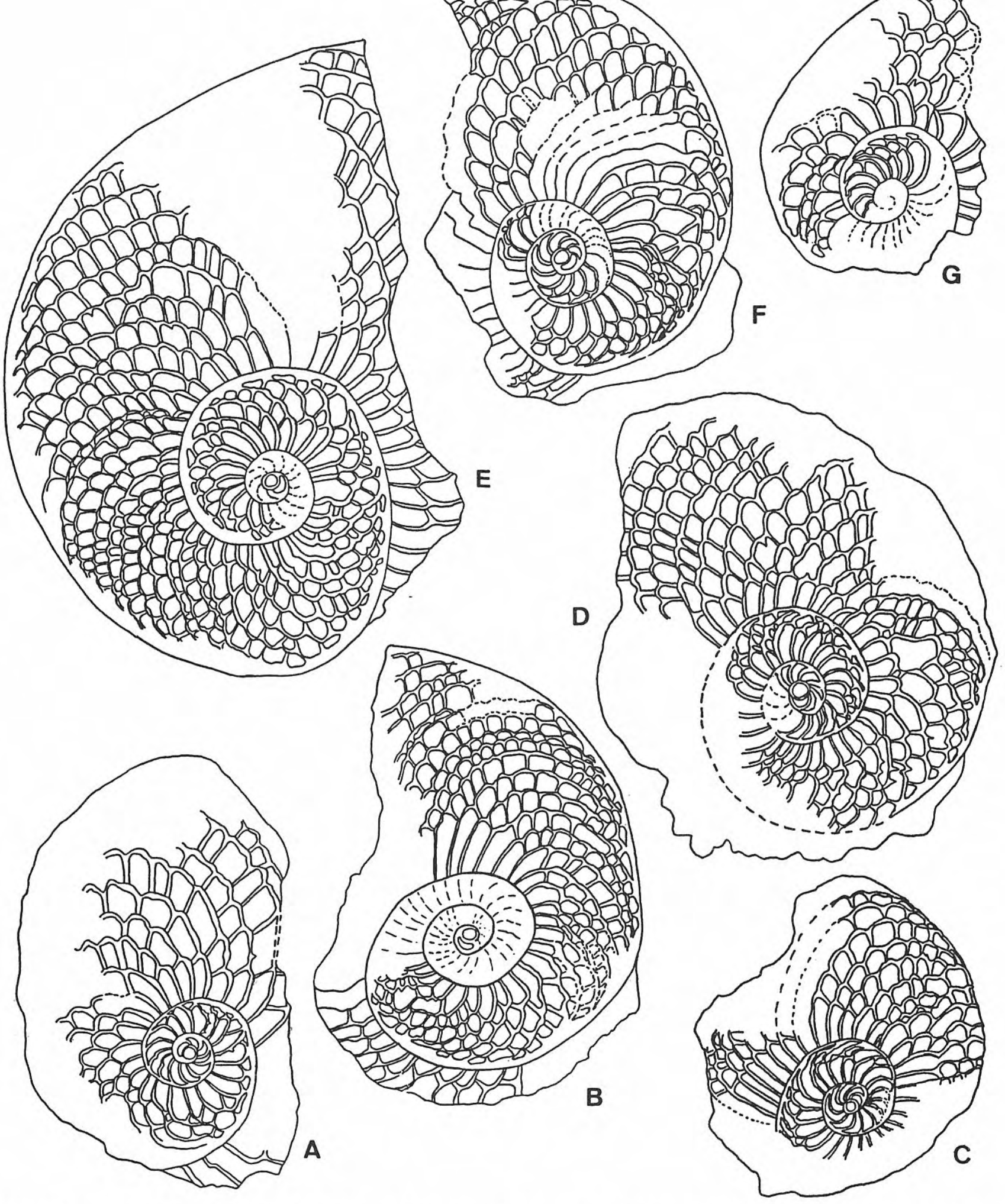

Figure 10. Heterostegina reticulata Rütimeyer, morphotype 1. Equatorial sections. x 20. Camara lucida drawings. A: PA-113, B, C, D, E and F: PA-117 and G: PA-119.

Pellatispira Boussac, 1906

Whereas Pellatispira occurs in numerous localities all around the Mediterranean and characterises late Eocene deposits of the Western Tethys, Biplanispira has been observed so far only in the Central (Indonesia) and Eastern (Bonin-Islands, Matsumaru, 1996) Tethys. It is surprising to find them both on the eastern shore of the 

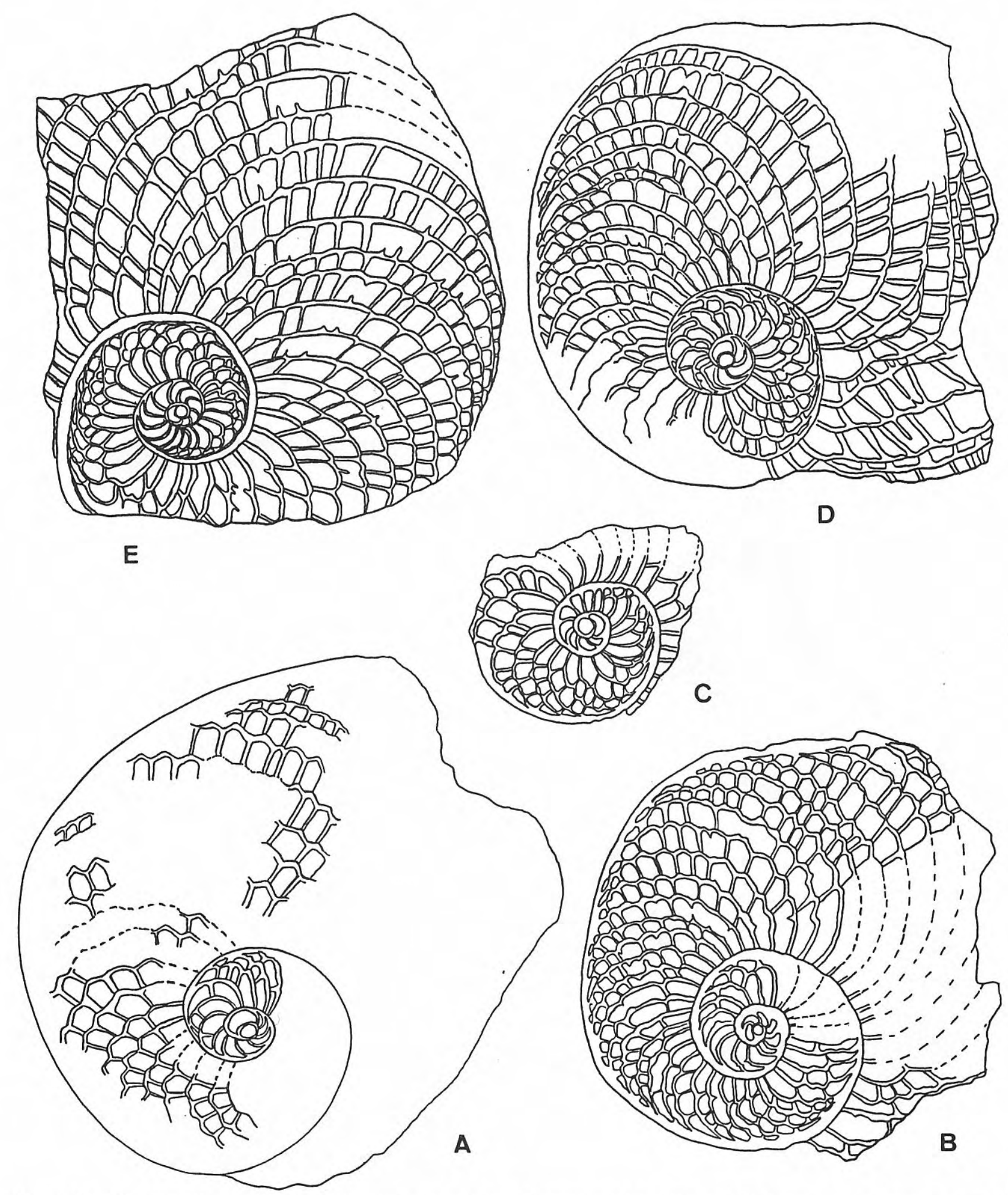

(1)

D

Figure 11. Heterostegina reticulata Rütimeyer, morphotype 2. Equatorial sections. x 20. Camara lucida drawings. A: PA105, B, C and D: PA-112 and E: PA-117.

Eocene Atlantic Ocean. In the Pyrenean realm, Pellatispira is rare and Biplanispira occurs together with a larger quantity of Pellatispira, in a single outcrop only, restricted to a single bed of $20 \mathrm{~cm}$ thickness. Apparently, the pellatispirids depend on very particular and rare environmental conditions outside of their "own" area in the central Indo-Pacific. The question arises, why these particular conditions are so restricted in space or in time or in both. In this paper, their presence in the sedimentary sequence and their exact location is indicated. A more detailed description of their morphology and a comparison with material from the central Indo-Pacific realm will be given elsewhere.

In constrast to nummulitids with their marginal cord, 
Plate I
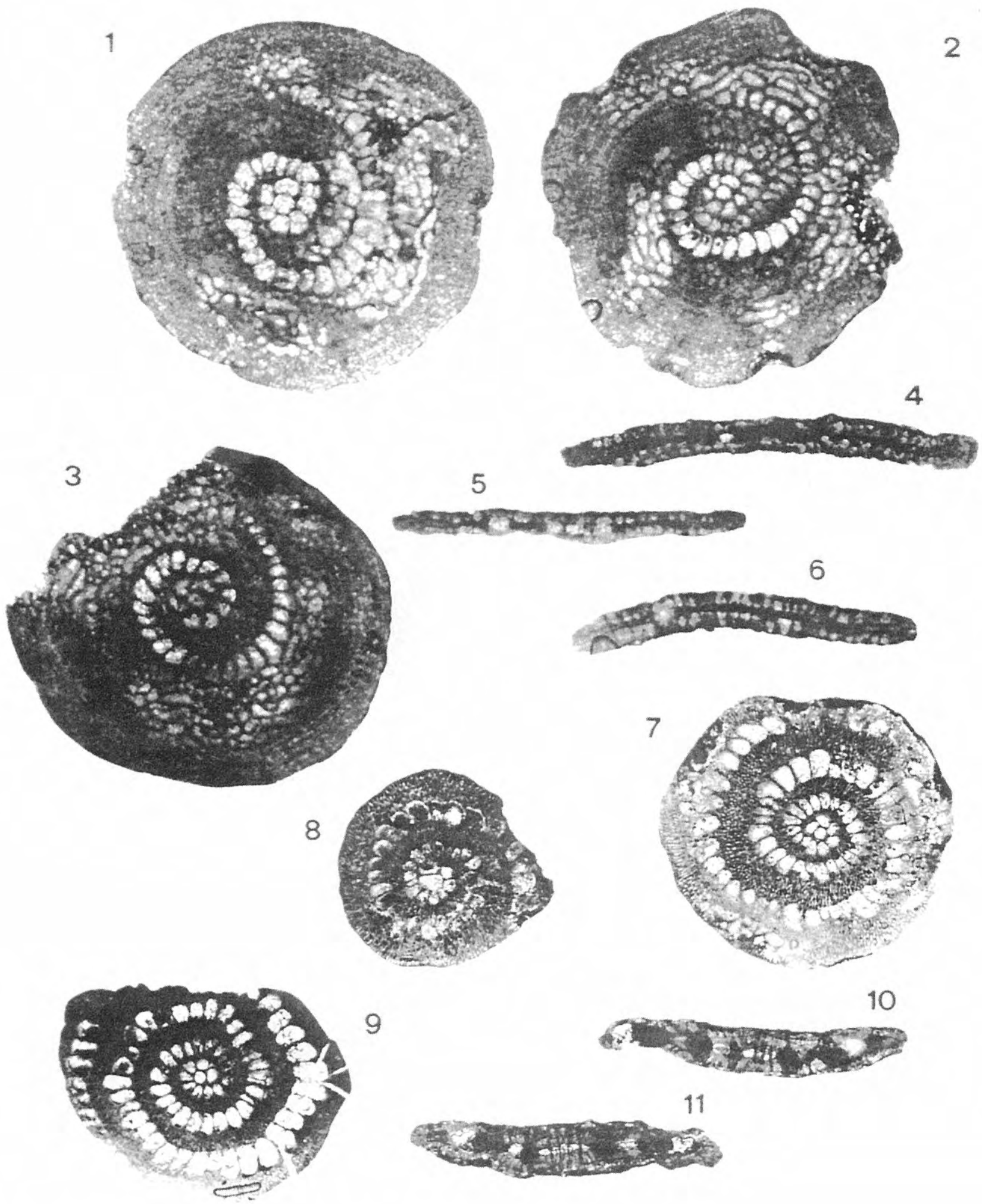

9

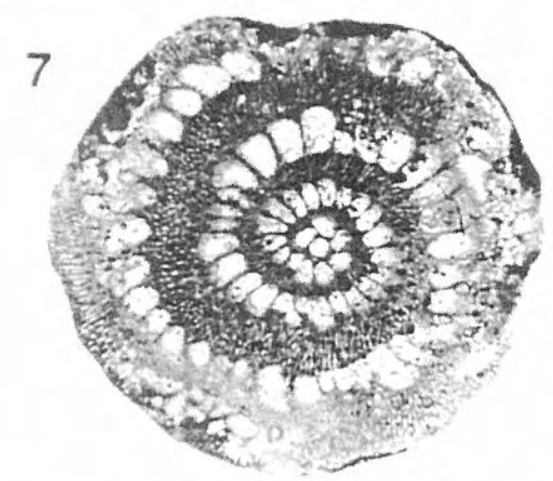

10

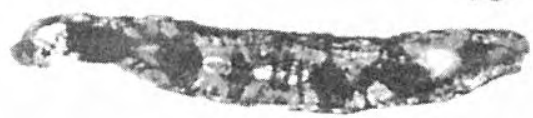

11

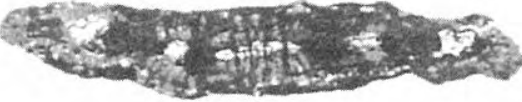

\section{Plate I}

1-6 Biplanispira sp. x10. Sample PA-117. 1-3: equatorial sections. 4-6: axial sections.

7-11 Pellatispira madaraszi Hantken. x10. Sample PA-117. 7-9: equatorial sections. 10-11: axial sections. 
Pellatispira and its allies have a marginal, supplemental skeleton dominated by parallel radially directed canals broadening the shell margin for more than the height of the spirally arranged chambers. In Biplanispira, the even more developed marginal supplemental skeleton is overgrown on both sides by chamberlets supplementing or substituting the equatorial chambers. Distribution and arrangement of intercameral foramina, oblique stolons and loop-holes (connections between chamber lumen and canal system) are not yet known in detail.

\section{Pellatispira madaraszi (Hanken, 1875) Pl. I, figs. 7-11}

1875 Nummulites madaraszi Hantken, 86, fig. 7.

1906 Pellatispira douvillei Boussac, 91, pl. 2, figs. 10-13.

1929 Pellatispira madaraszi Hantken; Tobler, 171, pl. 17, figs. 1-4.

1971 Pellatispira madaraszi Hantken; Ferrer, 6, pl. I, figs. 13.

1975 Pellatispira cf. madaraszi Hantken; Caus, 56.

The specimens from the Igualada basin have a discoidal shape reaching 2.45 to $5.15 \mathrm{~mm}$ in diameter. Their thickness varies from 0.52 to $0.91 \mathrm{~mm}$. The relationship diameter/thickness is 4.71 to 5.66 . The test is planispirally coiled with 5 to 9 chambers in the first whorl, 14 to 21 in the second and 24 to 32 in the third. The chamber volume in each growth step increases very slightly. The lateral surfaces are ornamented with papillae.

\section{Biplanispira Umbgrove, 1937}

\section{Biplanispira sp. Pl. I, figs. 1-6}

1971 Biplanispira? sp. Ferrer, pl. I, figs. 4,8.

The Biplanispira specimens have a flat discoidal test with planispirally (multi-spirally?) arranged chambers. The shell diameter varies from 4.86 to $7.34 \mathrm{~mm}$ and the thickness from 0.53 to $0.87 \mathrm{~mm}$. There are equatorial, spiral chambers in a loose coil for about two revolutions. After the third or forth chamber, lateral chamberlets start to overgrow the rapidly enlarging peripheral supplemental skeleton. The latter forms a thin equatorial layer with only few layers of marginal radial canals. In adult stages however, this layer tends to thicken at the shell periphery. Details about the disposition of intercameral foramina, stolons and loop-holes are not yet known.

As to the specific identity of the pyrenean Biplanispira we have to leave the question open until a comparison with material from the central Indo-Pacific realm will be possible. However, the Spanish specimens are, at least in part, truly biplanar and approach, by this character, the species B. absurda Umbgrove, 1938. Other specimens have a flat lenticular outline in axial section, with some prominent piles over the embryonic chambers resembling $B$. mirabilis depressa Hanzawa, 1957. No microspheric specimens are known in all species described so far as well as their biostratigraphic relationship, facts that hamper the assessment of intraspecific variation and specific delimitation.

\section{CONCLUSIONS}

The sediments exposed on the western slope of the Puig Aguilera encase representatives of three foraminiferal phyla evolving without interruption from Middle to Late Eocene: Assilina alpina group, Operculina gomezi group and Nummulites fabianii group. The three phyla are represented by species preceding the Priabonian ones: A. schwageri, $O$. roselli and $N$. ptukhiani (sensu Schaub, 1981), respectively. At level 105 (Figs. 4, 5) Heterostegina reticulata, at level 117 Pellatispira and Biplanispira, and, near to the reef crests, at about the same stratigraphic level, Silvestriella appear. They are interpreted as immigrants from the central Tethys, because no predecessors have ever been observed in the Mediterranean realm, and because their nepionic morphology does not exhibit any early, "primitive" trait.

The presence of $A$. schwageri, $O$. roselli and $N$. ptukhiani indicates an age of deposition prior to the deposits of the type locality of the Priabonian stage at Priabona, northern Italy. The presence of the immigrants in the same beds forbids to use the latter as exclusively Priabonian index fossils. In terms of the Shallow Benthic Zonation (SBZ), their first appearance occurs at the base or in SBZ 18.

\section{ACKOWLEDGEMENTS}

This work has received the support of DGICYT (PB930910). It is a contribution to the IGCP-393.

\section{REFERENCES}

Anadón, P. 1978. El Paleógeno continental anterior a la transgresión biarritziense (Eoceno medio) entre los rios Gaià y Ripoll (Provincias de Tarragona y Barcelona). Tesis doctoral. Inédita, 267 pp. (Resumen extenso en: Estudios Geológicos, 34, (1978), 341-440).

Anadón, P. y Marzo, M. 1986. Sistemas Deposicionales eocenos del margen oriental de la Cuenca del Ebro: Sector Igualada-Montserrat. XI Congreso Español de Sedimentología, Excursion 4, 4.1-4.59.

Bieda, F. 1950. Sur quelques foraminifères nouveaux ou peu connus du Flysch des Karpates polonaises. Rocznik Polskiego Towarzystwa Geologicznego, 18, 153-168.

Boussac, J. 1906. Développement et Morphologie de quelques Foraminifères de Priabona. Bulletin Societé Géologique de France, 4 (6), 88-97.

Caus, E. 1973. Aportaciones al conocimiento del anticlinal de Oliana. Acta Geologica Hispanica, 8, 7-10.

Caus, E. 1975. Bioestratigrafía del Eoceno medio y superior del Prepirineo Catalán (Y la zona de tránsito entre esta 
unidad y la cordillera prelitoral Catalana). Revista Española de Micropaleontología, 7, 297-316.

Caus, E. 1984. Bioestratigrafia i micropaleontologia de l'Eocè mitjà i superior del Pre-Pirineu Català. Institut d'Estudis Catalans, Barcelona, 83 pp.

Colombo, F. y Caus, E. 1984. El Terciario inferior marino (Ilerdiense) del cap de Salou (Tarragona, NE España). Revista Española de Micropaleontología, 16, 367-380.

Cushman, J.A. 1914. A Monograph of the Foraminifera of the North Pacific Ocean. IV. Bulletin United States Natural History Museum, 71, 43 pp.

Defrance, M.J.L. 1822. Dictionnaire des Sciences Naturelles, 25. Paris, F. G. Levrault.

Fermont, W.J.J. 1977. Biometrical investigation on the genus Operculina in recent sediments of the Gulf of Elat. Utrecht Micropaleontological Bulletin, 15, 111-147.

Ferrer, J. 1971a. El Paleoceno y Eoceno del Borde Suroriental de la Depresión del Ebro (Cataluña). Mémoires Suisses de Paléontologie, 90, 1-70.

Ferrer, J. 1971b. Presencia de macroforaminíferos priabonienses en el Eoceno de Igualada. Acta Geologica Hispanica, 6, 4 -7.

Gronovius, L. 1781. Zoophylacii Gronoviani. Haak et Soc. Leiden, 3, 241-380.

Hantken, M. 1875. Die fauna der Clavulina szaboi Schichten-1. Teil: Foraminiferen. Mitteilungen Jahrbuch Königlich - Ungarische Geolgische Anstalt, 4, 91 pp.

Hanzawa, S. 1957. Cenozoic foraminifera of Micronesia. Memoirs of the Geological Society America, 66, 1-163.

Herb, R. 1978. Some species of Operculina and Heterostegina from Eocene of the Helvetic nappes of Switzerland and from Northern Italy. Eclogae Geologicae Helvetiae, 71, 745-767.

Hottinger, L. 1964. Les genres Operculina et Heterostegina (Foraminifères) et leur utilité stratigraphique. Colloque Paléogène Bordeaux 1962, Mémoires Bureau Récherche Géologique et Minière, 28, 1013-1031.

Hottinger, L. 1977. Foraminifères operculiniformes. Mémoires du Muséum National d'Histoire Naturelle. Série C, 40, 1-159.

Loeblich, A.R. and Tappan, H. 1987. Foraminiferal genera and their classification. University of California, Los Angeles, $970 \mathrm{pp}$.
Matsumaru, K. 1996. Tertiary larger Foraminifera (Foraminiferida) from the Ogasawra Islands, Japan. Paleontological Society of Japan, Special paper 36, 1-226 pp.

Orbigny, A. d'. 1826. Tableau méthodique de la classe des Céphalopodes. Annales Sciences Naturelles (Paris), (1), 7, 96-314.

Orbigny, A. d'. 1839. Foraminifères. In: Sagra R. de la, Histoire physique, politique et naturelle de l'île de Củba. Bertrand, Paris, 224 pp.

Orbigny, A. d'. 1850. Prodrome de paléontologie stratigraphique universelle des animaux mollusques et rayonnés. Masson, Paris, 2 vol., 427 pp.

Reiss, Z. and Hottinger, L. 1984. The Gulf of Aqaba. Ecological Studies, 50, 354 pp.

Roissy, F. 1805. Histoire naturelle, générale et particulière des Mollusques (Buffon et Sonnini), 5. Dufart, Paris.

Romero, J. 1996. Estudio de los foraminíferos bentónicos del límite Eoceno medio - Eoceno superior de la cuenca de Igualada (Barcelona). Universidad Autónoma de Barcelona. Tesis de licenciatura. Inédita, $184 \mathrm{pp}$.

Rütimeyer, L. 1850. Ueber das schweizerische Nummulitenterrain mit besonderer Berücksichtigung des Gebirges zwischen den Thunersee und der Emme. Neue Denkschriften der Schweizerischen Naturforschende Gesellschaft, 11, 1-120.

Schaub, H. 1981. Nummulites et Assilines de la Téthys paléogène. Taxinomie, Phylogenèse et Biostratigraphie. Memoires Suisses de Paléontologie, 104, 1-236.

Serra-Kiel, J., Hottinger, L., Caus, E., Drobne, K., Ferràndez, C., Jauhri, A.K., Pavlovec, R., Piggnatti, J., Samsó, J.M., Schaub, H., Sirel, E., Strougo, A., Tambareau, Y., Tosquella, J. and Zakrevskaya, E. 1998. Large foraminiferal Biostratigraphy of the Tethyan Paleocene and Eocene. Bulletin Societe géologique de France, 169 (2), 281-299.

Silvestri, A. 1928. Di alcune facies Litho-Paleontologiche del Terziario di Derna, nella Cirenaica. Bolletino Società Geologica Italiana, 37, 109-113.

Tobler, A. 1929. Pellatispira im Priabonien von Lenk (berner Oberland). Eclogae Geologicae Helvetiae, 22, 2.

Umbgrove, J.H.F. 1938. A second species of Biplanispira from the Eocene of Borneo. Leidsche Geologische Mededelingen, 10, 82-89. 